\title{
VAŽNOST DUNAVA I ĐERDAPA U RATNIM OPERACIJAMA NA PODRUČJU JUGOSLAVIJE 1941-1944*
}

\begin{abstract}
APSTRAKT: Tokom Drugog svjetskog rata na jugoslovenskom prostoru Đerdap je predstavljao jednu od strateški najvažnijih tačaka. Ekspanzionistička politika Trećeg rajha napravila je od Dunava njegovu unutrašnju rijeku. Nesigurnost plovidbe po morima i činjenica da je Dunav bio direktna saobraćajna veza za naftonosnim poljima u Rumuniji povećavali su njegovu saobraćajnu važnost. Budući da su se na jugoslovenskom tlu nalazile neke od najvažnijih vodograđevina koje su olakšavale plovidbu kroz Đerdapske tjesnace, Đerdap i područje oko njega čvrsto su stajali u njemačkim rukama od aprila 1941. do početka septembra 1944. Članak je zasnovan na građi iz Arhiva Jugoslavije, Vojnog arhiva i Diplomatskog arhiva Ministarstva spoljnih poslova, objavljenim izvorima, kao i na stručnoj istoriografskoj literaturi.
\end{abstract}

Ključne riječi: Dunav, Đerdap, Jugoslavija, Njemačka, đerdapski piloti (locovi), Sipski kanal, plovidba

Žestoke vojne operacije koje su otpočele na tlu Evrope 1. septembra 1939. napadom Njemačke na Poljsku bile su praćene i snažnim diplomatskim, ekonomskim, obavještajnim i mnogim drugim vidovima borbe. Do izražaja je došla i strateška važnost pojedinih regiona, država, ali i vodenih tokova. Zbog svog geostrateškog značaja Dunav, a naročito Đerdap, postaju predmet obavještajnih borbi. Položaj na jugoistoku teritorije pod kontrolom sila Osovine i saobraćajna uloga zbog koje je bio od izuzetnog značaja za pokretanje ratne mašinerije Trećeg rajha, činili su da se pitanje Dunava posmatra kao jedno od najvažnijih pitanja i u Berlinu i u Londonu.

* Rad je deo projekta Srpsko društvo u jugoslovenskoj državi u 20. veku: između demokratije i diktature (177016), koji finansira Ministarstvo prosvete, nauke i tehnološkog razvoja Republike Srbije. 
Britanska obavještajna služba imala je planove o diverzantskim akcijama čiji je cilj bio onemogućavanje njemačke plovidbe kroz Đerdapski sektor. Prema nekim podacima, britanska obavještajna služba je još krajem 1938. razradila plan pod nazivom Dunavska operacija, sa ciljem onemogućavanja Njemačke da koristi Dunav u svoje ekspanzionističke svrhe, a naročito da se snabdijeva naftom iz Rumunije i žitaricama sa Balkana. Prvi sastanci u vezi sa sprečavanjem njemačke plovidbe na Dunavu održani su u martu 1939, a konkretni koraci su preduzeti već početkom ratnih operacija. Prema britanskom planu, postojala su tri načina borbe. Prvi je podrazumjevao otkup brodova koji su plovili pod njemačkom zastavom u cilju slabljenja njemačke trgovačke flote. Međutim, kako navodi Elizabet Barker, otkupljivani su i brodovi koji su plovili pod rumunskom, jugoslovenskom, francuskom i belgijskom zastavom. Prethodno je britanska obavještajna služba dobila nadzor nad plovnim parkom britanskog društva za plovidbu Dunavom - Anglo-Danubija (The Anglo-Danubian Shipping and Trading Corporation Ltd), koje je raspolagalo sa tri motorna broda (Elisabeth, Britain i Scotland), dva motorna tanka (Lord Byron i Psicho) i četiri tanka (Glasgow, Brussells, Schell I i Schell II), sa sjedištem u Bukureštu. ${ }^{1}$

Drugi način borbe podrazumjevao je potkupljivanje osoblja na brodovima svih zastava koje su saobraćale Dunavom, a naročito đerdapskih pilota, za neprijateljsko držanje prema Njemačkoj. Treći, najradikalniji vid borbe, obuhvatao je dejstvovanje eksplozivom po strmim đerdapskim obalama. O tome su postojala izvjesna saznanja krajem 1939. godine i u Berlinu i u centrali Međunarodne dunavske komisije (MDK) u Beogradu. Sabotaže su ponajviše očekivane na 967. i 968. kilometru Dunava, a planirano je da budu izvedene potapanjem šlepova ili „obrušavanjem zemlje“, kako je njemačkog vojnog atašea u Beogradu izvjestio Velizar Ninčić, predsjedavajući MDK. S obzirom na to da Njemačka nije više bila član MDK i da njeno postojanje nije ni priznavala, postupak V. Ninčića je vrlo karakterističan. ${ }^{2}$

Prema britanskim planovima, postojala su tri „pogodna“ dijela Đerdapskog sektora za sabotažna dejstva. U tjesnacu Greben mogao je biti miniran potporni zid, u Kazanu su mogle biti obrušene izuzetno strme litice, dok je u Sipskom kanalu (na samim Željeznim vratima) planirano potapanje šlepova ispunjenih cementom. Za ovakva dejstva na Đerdapu bio je zadužen Džulijus Henau, a planiranje je bilo povjereno pomorskom atašeu

${ }^{1}$ Arhiv Jugoslavije (AJ), Glavna direkcija rečnog saobraćaja (331), fascikla 3, broj 2001; Elisabeth Barker, Britanska politika prema jugoistočnoj Evropi u Drugom svjetskom ratu, Zagreb 1978, 48-49; Nikola Milovanović, Pukotine kraljevstva. Rat obaveštajnih službi na tlu Jugoslavije, I, Beograd 1978, 264.

2 AJ, Centralni presbiro Predsedništva Ministarskog saveta Kraljevine Jugoslavije (38), 545-710; Marinko Paunović, Đerdap i Timočka Krajina, Zagreb 1970, 696. 
u Bukureštu i Beogradu Maksu Despardu i direktoru Naval Intelligence-a admiralu Godfriju. Međutim, pod njemačkim pritiskom jugoslovenske vlasti su protjerale Dž. Henaua iz Beograda. ${ }^{3}$ Neuspjehom je završen i plan o potapanju pet šlepova natovarenih kamenom i cementom, koje je u kanalu Juc, decembra 1939, trebalo da potopi grupa predvođena Čehom Josipom Rezlerom, koji je već godinama boravio u Jugoslaviji. Potapanje ovih šlepova neposredno pred sezonu redovne obustave plovidbe zbog leda trebalo je da zaustavi plovidbu za narednih gotovo godinu dana, jer ni čišćenje plovnog puta ne bi bilo moguće zbog vremenskih prilika. Kašnjenje sa isporukom eksploziva i raniji početak sezone leda na Dunavu onemogućili su izvođenje ove akcije. ${ }^{4}$

Britanska obavještajna služba radila je na iskopavanju komora i hodnika u klisuri Kazan od septembra 1939. Zbog blizine susjedne obale i konfiguracije terena posao je bilo teško izvršiti u tajnosti, pa je već u decembru rad prekinut. Na britanska podsticanja da sam nastavi sa radom jugoslovenski Generalštab nije pristajao, u namjeri da ne provocira Nijemce. U britanskim dokumentima pisalo se da je aktivnost nastavljena i poslije decembra 1939. „naporima, ubeđivanjem i političkim pritiskom na princa namesnika i, gde je potrebno nuđenjem velikih svota kao mito, da se obnove radovi za plan Kazan“. Britanci su jugoslovenskom Generalštabu nudili i alternativu, u rušenju vodograđevina na Grebenu i Jucu i potapanju 16 plovila Šulcove flote „koje smo početkom 1940. kupili u ove svrhe, a sada ih predali jugoslovenskom Generalštabu“. ${ }^{5}$

${ }^{3}$ Opisujući Džulijusa Henaua Milorad Janković navodi: „Predstavnici Abvera i Gestapoa u Beogradu prozvali su mistera Hanaua 'čovek s bezbroj lica'. To zato što niko tačno nije znao kako on fizički izgleda! Čas je imao crnu kosu, čas riđu, čas brkove, čas je bio bez brkova, čas je imao naočare, čas nije, čas je bio sed, čas plav!“” (Milorad Janković, Rat špijuna u Kraljevini Jugoslaviji, Zagreb 1982, 68).

${ }^{4}$ Boško Antić, Rečna ratna flotila Narodnooslobodilačke vojske Jugoslavije, Beograd 1991, 10; Nikola Račić, Đerdap, Beograd 1965, 104.

${ }^{5}$ U literaturi se često opisuje i pokušaj Matije Lončarića Brušlije iz Paraćina. On je 1940. pokušao da postavi ogromne količine eksploziva u, prethodno iskopanu, duboku bušotinu na Malom Štrpcu, 3 kilometra uzvodno od Trajanove table. Cilj mu je bio da izazove snažnu eksploziju kojom bi se velike količine kamena i čitavi komadi stjena našli u Kazanu. Pretvarajući se da vrši geološka mjerenja, a uz pomoć kovača Milovana Pavlovića, napravio je bušotinu i u nju postavio 18 kg eksploziva. Donošenje novih 35 kg i izvršenje akcije omela je informacija njemačkih obavještajnih službi data jugoslovenskim vlastima i zahtjev da se Matija Lončarić uhapsi. On je uspio izbjeći hapšenje i, kako se dalje navodi, pobjeći u Veliku Britaniju. Lončarić je, navodno, nešto prije ovog pokušaja, uspio oštetiti kameni zid na Grebenu, zbog čega su tešku havariju pretrpjela dva njemačka tankera koja su prevozila naftne derivate iz Rumunije (Marko Pivac, Rad britanske tajne službe u Jugoslaviji u predvečerje Aprilskog rata 1941, Istorija 20. veka, br. 1/2010, 193-212; N. Račić, n. d., 104-105; M. Paunović, n. d., 697-698; B. Antić, Rečna ratna flotila NOVJ, 10). 
O mogućnosti da agenti britanskih obavještajnih službi eksplozivom ruše strme i stjenovite obale Đerdapa, njemačko Ministarstvo inostranih poslova izvještavao je i poslanik u Beogradu Viktor fon Heren. U koordinaciji sa jugoslovenskom obavještajnom službom ove akcije su predupređene. Zbog opasnosti od sabotaže u Đerdapskom sektoru sprovođene su i posebne bezbjednosne mjere u pogledu kretanja brodova i ljudi. Na prijedlog jugoslovenskog Ministarstva inostranih poslova osnovan je Stalni komitet za bezbjednost plovidbe na Dunavu. Komitet je osnovan kao savjetodavno tijelo, a njegovi članovi su bili predstavnici nekoliko ministarstva - Ministarstva inostranih poslova, Ministarstva unutrašnjih poslova, Ministarstva vojske i mornarice, Ministarstva saobraćaja i Ministarstva finansija. Na čelu Komiteta nalazio se Velizar Ninčić. Zadatak Komiteta bio je da predlaže nadležnim ministarstvima „sve potrebne mere za bezbednost plovidbe na jugoslovenskom delu Dunava“. Komitet je naročito obraćao pažnju na sigurnost plovidbe $u$ Đerdapskom sektoru. Odluka jugoslovenskih vlasti o formiranju naročitog tijela koje će se starati o bezbjednosti dunavske plovidbe kroz Jugoslaviju naišla je na veliku pažnju italijanskih i njemačkih štampanih medija koji su pisali o „rigoroznoj kontroli“ koju sprovode jugoslovenske vlasti. Osim toga, jugoslovenske vlasti su uputile jednu pješadijsku četu, vod zemaljske artiljerije i vod protivavionskih mitraljeza iz 9. pješadijskog puka na Sipski kanal. Takođe, iz Novog Sada su upućeni monitori Drava u Tekiju i Sava u Veliko Gradište, kao i četiri motorna čamca u Kladovo, Tekiju, Donji Milanovac i Veliko Gradište. ${ }^{6}$

Jugoslovenska i rumunska vlada dogovorile su se početkom aprila 1940. o sprovođenju zajedničkih mjera u cilju povećanja bezbjednosti dunavske plovidbe, a u strahu od znatnijeg uplitanja njemačkih snaga $u$ kontrolisanje sigurnosti plovidbe. U ljeto iste godine rumunska strana je formirala posebnu vojnu jedinicu pod nazivom Gornji dunavski sektor, čiji se štab nalazio u Oršavi a naoružani punktovi bili raspoređeni na nekoliko mjesta u Sektoru (Vir, Ljubkova i Krakul Turčului). Rumunska vojska je postavila i teška artiljerijska oružja na punktovima nizvodno od Đerdapa

${ }^{6}$ AJ, Ministarstvo saobraćaja Kraljevine Jugoslavije (148), fas. 135, pov. br. 27/40; АJ, 38-545-710, Време, 16. октобар 1940; АJ, 38-545-710, Münchener Neueste Nachrichten, 27. 4. 1940; AJ, 38-545-710, Il Resto del Carlino, 12. 4. 1940; Aprilski rat 1941. Zbornik dokumenata, I, priredio Dušan Gvozdenović, Beograd 1969, 505-506; Душан Лукач, Иниеересоваюе у наиисииичкој Немаикој за изі̄раgюу хияроенеріеииской сисиеема у Ђерgайу, Balcanica, br. VI/1975, 189-199; Dušan Lukač, Treći Rajh i zemlje jugoistočne Evrope, II, Beograd 1982, 341-342; E. Barker, n. d., 51; Драган Алексић, Привреgа Србије у Друіом свейском райу, Београд 2002, 116; N. Milovanović, n. d., I, 266-267; Jovan Marjanović, Draža Mihailović između Britanaca i Nemaca, Zagreb 1979, 25; Слободан Бранковић, Немачка је иочела рай на Балкану 1941. на Ђерgайу найаgом на Краљевину Јуїославију, Развитак, бр. 1-2/1991, $18-29$. 
(Korabija, Turnu Magurele, Zimničea, Petrošani, Tulčea, Đurđu, Oltenica), a njihovi patrolni čamci kružili su i deltom Dunava. ${ }^{7}$

Herman Nojbaher, koji je bio zadužen za privredna pitanja pri njemačkom poslanstvu u Bukureštu, nazivao je britanske planove „pustolovnim“, „avanturističkim“ i „fantastičnim“. Njemačka obavještajna služba uspjela je da u aprilu 1940. otkrije dva broda koja su plovila rumunskim dijelom Dunava prema Đerdapu. Brodovi su zaustavljeni u luci Đurđu, gdje se nalazio jedan od tri njemačka pontonska mosta napravljena radi prebacivanja trupa u Bugarsku. Na brodovima su otkrivene velike količine eksploziva, tehničke opreme, oružja i mnoštvo britanskih vojnika i mornara. Štampa je ovakve pokušaje nazivala „atentatima na plovnost Dunava“, njemački listovi su postavljali pitanje „šta će ti ludaci da sutra učine“, dok je britanska štampa sve negirala, nazivajući ove informacije „bajkama“. Vladimir Velebit je, mnogo godina kasnije, u svojim Sećanjima za ove pokušaje rekao da su bili „naivno zamišljeni i vrlo nestručno sprovedeni“. Sudeći prema izvještaju britanskog poslanika iz Beograda Ronalda Kembela, knez Pavle je rezignirano upitao dopisnika Tajmsa „kako u tim okolnostima možemo (misli se na Britance - prim. aut.) da rizikujemo da takvim akcijama dovučemo Nemce na Balkan“. 8

Britanske akcije $\mathrm{u}$ pogledu otkupljivanja plovila i potkupljivanja osoblja (naročito pilota) dale su izvjesne rezultate. Kako navodi Marinko Paunović, Britanci su otkupili 5 tegljača i 50 šlepova od društva Šulc i Dajč. Ova plovila su ubrzo sklonjena u pančevačko pristanište, a neka od njih su korišćena $u$ jednom kasnijem pokušaju zaprečavanja plovnog puta $u$ Đerdapu. ${ }^{9}$ Radi upravljanja akcijom otkupa plovila, britanska vlada je osnovala The Goeland company, koja je rad započela u februaru 1940, a u junu iste godine preuzela dunavske brodove pod francuskom zastavom. Ubrzo potom, Britanci su započeli evakuaciju svih plovila kojima su raspolagali na Dunavu. Najveći dio njihovih plovila stigao je do Istanbula, gdje su i ostali do završetka ratnih operacija. ${ }^{10}$

Krajem marta i početkom aprila 1940. znatan broj pilota Đerdapske administracije, primivši novac „od agenata izvesnih zaraćenih strana“,

${ }^{7}$ P. Opriș, Security Measures Taken by the Romanian General Staff in 1941 for the Danube in Order to Prevent the Development of International Terrorism, u: The Danube, European Security and Cooperation at the Beginning of the 21th Century (zbornik radova), Bucharest 2002, 63-69.

${ }^{8}$ Herman Nojbaher, Specijalni zadatak Balkan, Beograd 2005, 59-60; Britanci o Kraljevini Jugoslaviji, III, priredio Živko Avramovski, Beograd 1996, dok. br. 157, 437-438; Vladimir Velebit, Sećanja, Zagreb 1983, 21.

\footnotetext{
${ }^{9}$ M. Paunović, n. d., 696-697.

${ }^{10}$ Detaljnije u: E. Barker, n. d., 48-49.
} 
napustio je službu. ${ }^{11}$ Iako je Velizar Ninčić, u depeši Ministarstvu inostranih poslova od 29. januara 1941, pisao o svojim saznanjima da sovjetske obavještajne službe „vrbuju u Đerdapu pilote i drugo stručno brodarsko osoblje", ${ }^{12}$ đerdapski piloti su napuštali službu pod uticajem britanske obavještajne službe. Od ukupno 43 službena pilota, čak 19 ih je napustilo službu, čime je bilo znatno ugroženo normalno odvijanje plovidbe. Među pilotima koji su tada napustili službu bilo je 9 Jugoslovena (Tadija Udovičić, Đorđe Trandafilović, Nikola Kocić, Svetomir Kocić, Krsta Ninić, Jovan Vučić, Ilija Radulović, Jovica Mihajlović, Jerolim Vukić), 7 Rumuna (George Gorun, Anastasis Budulan, Jon Muska, Nikola Bocoaka, Radukan Kirica, Jon Peroj, Vasilije Teodorovići), Bugarin (Todor Fenehemov), Čeh (Adolf Navratil) i Mađar (Jozef Horvat). Piloti su navodili nekoliko razloga zbog kojih su, navodno, napuštali službu: nezadovoljstvo osiguranjem kod osiguravajućeg društva Nacional, nezadovoljstvo prinadležnostima, strogo kažnjavanje pilota od strane MDK u slučaju plovidbenih nezgoda, narušeno zdravlje uslijed prirode posla, ili uopšteno porodične razloge. Pilot Vasa Burkić je dao čvrsto obećanje da će napustiti službu, ali je, uzevši prve tranše novca (polovina od ukupne sume, unaprijed za pet godina), zadržao i svoj posao u Đerdapskoj administraciji. Pilotima koji su napustili službu, prema svjedočenju Tadije Udovičića, zaračunata je mjesečna nadoknada od 915 švajcarskih franaka. ${ }^{13}$

U jednom sovjetskom dokumentu iz aprila 1945. navodi se da su ponudu pilotima dali trgovci iz Oršave, braća Vili i Feri Ekštajn, da je agitaciju vodio Tadija Udovičić i da su piloti bili povezani sa nekoliko britanskih oficira u Turn Severinu (inspektor Blajmel i kapetan Lerting) i Budimpešti (Ker, Holer i Džonson Ridvar). Sam Tadija Udovičić, nekoliko godina kasnije, svjedočio je da je sve počelo kada je ,jedan ćopavi Englez u civilu, koji je bio inspektor engleskog društva Goeland, došao u Oršavu“, povezao se sa braćom Ekštajn i stupio u kontakt sa Čehom Navratilom. Konačni dogovor postignut je u prostorijama engleske agencije u Turn Severinu. Tamo je svaki od pilota dobio „malu cedulju formata osmine tabaka, na kojima je bilo napisano tri do četiri rečenice engleskim jezikom sa potpisom Engleza,

${ }^{11}$ Zbog složenosti plovidbe kroz Đerdapski sektor uvedena je obavezna pilotaža za sve brodove koji su prolazili kroz taj dio Dunava. Đerdapski piloti (locovi) su, uglavnom, pripadali lokalnom stanovništvu, iz naselja na dunavskim obalama u Đerdapu. Osim što su bili vični plovidbi, odlično su poznavali ćudi rijeke u ovom dijelu toka i raspored podvodnih stjena koje su mogle uticati na normalno odvijanje plovidbe.

${ }^{12}$ AJ, Ministarstvo inostranih poslova Kraljevine Jugoslavije (334), 2-15.

${ }^{13}$ AJ, 148-135, pov. br. 92/40; AJ, 331-81, Referat o Đerdapskom sektoru Dunava; Diplomatski arhiv Ministarstva spoljnih poslova (DAMSP), Politička arhiva (PA), 1947, Đerdapska administracija, f-85, dosije 7, 427358; DAMSP, PA, 1947, Đerdapska administracija, f-85, dosije 7, 427345; N. Milovanović, $n$. d., I, 267-268. 
koji je izjavio da predstavlja Englesku Imperiju“. Zatim su „kod potpisa tog Engleza, stavljali jedan znak u obliku znaka navoda, napisan mastilom, i to na svakoj cedulji“. Kako dalje svjedoči T. Udovičić: „Nama Jugoslovenima rečeno je da sa tim nalogom treba da odemo u Beograd i da tamo u engleskoj ambasadi dobijemo dinare." Tek potom, piloti su podnijeli ostavke. U britanskoj ambasadi u Beogradu isplaćeno im je po 340.000 dinara. Na insistiranje Njemačke tim pilotima je zabranjeno da borave bilo gdje u blizini Đerdapa. Od septembra 1940. piloti su bili internirani u Brusu, a od januara 1941. prešli su u Valjevo, ali je strogi državni nadzor nad njima ostao. Pušteni su na slobodu tek poslije pada vlade Dragiše Cvetkovića, 27. marta 1941. godine. ${ }^{14}$

Kako bi se popravilo brojno stanje među pilotima, Administracija je bila primorana da angažuje već penzionisane pilote i da u najkraćem roku raspiše konkurs za prijem 20 učenika-pilota, kao i da poveća broj tzv. privatnih pilota u svojoj službi. Prijedlog da se piloti u ostavci još neko vrijeme koriste kao privatni piloti nije ozbiljnije razmatran. Na konkurs za prijem učenika-pilota prijavilo se 52 kandidata, a u službu je 1. jula 1940. primljeno njih 19 (8 Jugoslovena, 7 Rumuna i po jedan Slovak, Čeh, Mađar i Grk). ${ }^{15}$ Plovidbena društva su predložila 23 kandidata koji bi sprovodili njihove brodove u statusu privatnih pilota. Tek poslije svih ovih mjera, Đerdapska administracija je uspjela anulirati štetu nanijetu ostavkama pilota, pošto je u drugoj polovini 1940. godine imala 26 službenih pilota, 5 penzionisanih pilota na privremenom radu i 19 učenika-pilota (ukupno 50). Uz to, na Đerdapu je radilo i 29 privatnih pilota, koji su pripadali brodarstvima raznih zastava. ${ }^{16}$

Ubrzo po ulasku njemačkih trupa na teritoriju Rumunije iz Jugoslavije je jasno uočena i njihova sve veća koncentracija na obalama Dunava u

${ }^{14}$ Dio ovih pilota su uhapsile njemačke vlasti ubrzo poslije sloma Kraljevine Jugoslavije. Prema knjigama banjičkih logoraša Svetomir Kocić, Ilija Radulović i Nikola Kocić su bili zatočeni od 12. novembra, Krsta Ninić od 2. decembra 1941, a u logoru su ostali sve do 24. aprila 1942, kada su „odvedeni na rad“. Jovan Vučić je na Banjici bio od 17. septembra 1941, sve do 24. aprila 1942. kada se našao u grupi od 693 zatočenika upućenih u logore u Norveškoj (DAMSP, PA, 1945, Saobraćaj, f-29, dosije 17, 7679; DAMSP, PA, 1945, Saobraćaj, f-29, dosije 18, 7694; DAMSP, PA, 1945, Saobraćaj, f-29, dosije 20, 7738; DAMSP, PA, 1945, Saobraćaj, f-29, dosije 20, 7742; DAMSP, PA, 1946, Dunav, f-20, dosije 22, 15489; DAMSP, PA, 1947, Đerdapska administracija, f-85, dosije 7, 427331; DAMSP, PA, 1947, Đerdapska administracija, f-85, dosije 7, 427358; DAMSP, PA, 1947, Đerdapska administracija, f-85, dosije 7, 427334; Радоје Р. Зечевић, Србија и међунарояни йоложај Ђерgайа, 49; Logor Banjica. Logoraši, I, priredile Evica Micković i Milena Radojčić, Beograd 2009, 97, 135-136, 168).

${ }^{15}$ Primljeni Jugosloveni su bili: Dušan Bonderović, Franja Maras, Đorđe Fasujević, Ljubomir Barbulović, Đorđe Sorojević, Aleksandar Makulović, Milutin Paulesković i Ivan Dračar (AJ, 148-135, pov. br. 238/40).

${ }^{16}$ AJ, 148-135, pov. br. 238/40. 
Đerdapskom sektoru. Analizirajući kretanje njemačkih trupa po Rumuniji, ministar inostranih poslova Kraljevine Jugoslavije Aleksandar Cincar-Marković isticao je da su „trupe najvećim delom dislocirane u južnoj Olteniji, južnoj Vlaškoj, dakle blizu Dunava, u Dobrudži i manjim delom u Erdelju i Moldaviji. U Banatu su trupe samo na prolazu. Dakle, ne radi se ni samo o čuvanju petrolejskih polja, koja se nalaze duž padina Karpata, a ne blizu Dunava, Pruta ili u Dobrudži."17 Početkom februara 1941. prvi njemački vojnici su stacionirani u Oršavi, a dr Velizar Ninčić je javio da su naspram Sipskog kanala već tada bila postavljena dva reflektora, koja su obasjavala jugoslovensku teritoriju, preciznije instalaciju lokomotivske vuče. ${ }^{18}$ Nijemci su, prema podacima do kojih je došao V. Ninčić, sakupljali detaljne informacije o putevima i pristaništima u Rumuniji, a naročito ih je interesovao „kapacitet pristaništa, saobraćaj sa pozadinom, mogućnost pretovara itd." ${ }^{19}$

Poslije prevrata u Beogradu 27. marta 1941, kojim je oborena vlada koja je dva dana ranije potpisala pristupanje Kraljevine Jugoslavije Trojnom paktu, na sastanku u noći 27/28. marta Adolf Hitler donosi Direktivu br. 25 o hitnom preduzimanju napada na Jugoslaviju. Nakon uništenja jugoslovenske oružane sile, koncentričnim napadima iz više pravaca bilo je potrebno postići „brzo otvaranje saobraćaja na Dunavu i zauzimanje rudnika bakra u Boru". U svom naređenju Vrhovnoj komandi kopnenih snaga i ratnog vazduhoplovstva od 31. marta 1941. A. Hitler je posebno naglasio da se „svim sredstvima“ moraju „pojačati mere za zaštitu Dunava protiv potapanja brodova, plovnih mina itd. ${ }^{20} \mathrm{~S}$ obzirom na njemačke planove o napadu

${ }^{17}$ Citirano prema: Aprilski rat 1941. Zbornik dokumenata, II, priredio Antun Miletić, Beograd 1987, dok. br. 7, 25-27.

${ }^{18}$ Izvođenjem regulacionih radova krajem XIX vijeka nije rješen problem plovidbe kroz Đerdapski sektor. Prevelika brzina matice u Sipskom kanalu nametnula je potrebu za ukazivanjem pomoći brodskim povorkama. Za to je korišćen tegljač (tuer) Vaškapu. Kako je početkom Prvog svjetskog rat tegljač prevezen na donji Dunav, okupacione snage su izgradile željezničku prugu i vuču brodova kroz Sipski kanal sprovodile pomoću lokomotiva sa kopna. Razorena u povlačenju okupatora, a obnovljena 1928, lokomotivska vuča je predstavljala neophodnost za prolazak brodova kroz Sipski kanal. Omogućavala je brži i sigurniji prolazak, ali i davala mogućnost za prolazak čitavih povorki. Bez njene pomoći brodske povorke su se morale rastavljati, šlepovi tegliti pojedinačno, a sve to su mogli izvršavati samo tegljači veće snage, uz enormnu potrošnju pogonskog goriva, a samim tim i troškova i vremena transporta. Lokomotivska vuča je sve do izgradnje HEPS Đerdap predstavljala ključ za prolazak kroz najzahtjevniji dio Đerdapskog sektora (АJ, 38-545-710, Полийика, 29. децембар 1931; Време, 6. децембар 1938).

${ }^{19}$ AJ, 334-2-15; Vojni arhiv (VA), fond Vojska Kraljevine Jugoslavije (VKJ), kutija 12, fascikla 5 , dok. br. 21.

${ }^{20}$ VA, VKJ, k. 3a, f. 1, dok. br. 8; Aprilski rat, II, dok. br. 126, 134, 147, str. 346350, 383-384, 450-454; AVNOJ i revolucija. Tematska zbirka dokumenata 1941-1945, priredili Slobodan Nešović i Branko Petranović, Beograd 1983, 15-16; Dokumenti o spoljnoj politici Socijalističke Federativne Republike Jugoslavije 1941-1945, I, priredio Bogdan Popović, Beo- 
na Sovjetski Savez, Dunav je imao izuzetnu važnost jer je predstavljao prirodnu sponu sa Crnim morem, ali i zbog mogućnosti njegovog neposrednog povezivanja sa prilaznim linijama budućeg istočnog fronta.

Nijemci su povukli sve svoje plovne objekte iz Đerdapskog sektora još 28. marta, a ubrzo su i svoja plovila prestali puštati u jugoslovenske vode, iako su „dobili uveravanja o potpunoj bezbednosti plovidbe kako našim Dunavom, tako i Đerdapskim sektorom“. Izvještaji V. Ninčića o obustavi njemačke plovidbe na Đerdapu, kao i o povećanju broja njemačkih aviona smještenih u Turn Severinu, bili su jasni nagovještaji skorog otpočinjanja ratnih dejstava protiv Jugoslavije. Još 31. marta sa Đerdapa je javljano da se „nemački i rumunski oficiri često viđaju na obali Dunava sa kartama i durbinima. Isti osmatraju našu obalu i lokomotivsku vuču." Velizar Ninčić je jasno naglasio: „Mišljenja sam da su ovi oficiri studirali našu lokomotivsku vuču na Sipskom kanalu." Takođe, prema izvještaju sa Đerdapa, od 4. aprila, primjetno je bilo i kretanje njemačkog ratnog broda, „obojenog sivomaslinastom bojom“, koji, „sa još dva manja motorna broda, na Dunavu oko Oršave vrši kontrolu i izviđanje“. U izvještaju se još navodi da „ovi brodovi preko dana (skoro svakog časa) i ujutro vrše kontrolu ka Donjem Milanovcu i Kladovu (preko Sipskog kanala). Brodovi su naoružani, a zvuk motora se ne čuje." U izvještaju od 4. aprila 1941. V. Ninčić je pisao i da je „dosad bilo u Turnu Severinu 30 nemačkih vojnih aviona, a sinoć ih je stiglo još 26 ". 21

Jugoslovenski poslanik u Bukureštu Aleksandar Avakumović izvjestio je 2. aprila Ministarstvo inostranih poslova o razgovoru koji je vodio sa otpravnikom poslova njemačkog poslanstva. Predmet njihovog razgovora bili su odnosi Njemačke i Jugoslavije u svjetlu događaja od 27. marta. Avakumović je pisao: „Iz onog što mi je rekao nemački otpravnik poslova (delimično mi je čitao uputstva, koja je dobio iz Berlina), proizilazi: Hitler je lič-

grad 1988, pril. br. 2, str. 415-417; Balkanski ugovorni odnosi 1876-1996. Dvostrani i višestrani međunarodni ugovori i drugi diplomatski akti o državnim granicama, političkoj i vojnoj saradnji, verskim i etničkim manjinama, II (1919-1945), priredio Momir Stojković, Beograd 1998, 474-476; 27. mart 1941. Tematska zbirka dokumenata, priredili Branko Petranović i Nikola Žutić, Beograd 1990, 539-540; Ešref Vražalić, Napad na Jugoslaviju i njena okupacija 1941. godine, Beograd 1957, doktorska disertacija u rukopisu, 34; Velimir Terzić, Slom Kraljevine Jugoslavije 1941. Uzroci i posledice poraza, II, Beograd 1983, 33-34, 51-52, 54-55; Bogdan Krizman, Hitlerov 'Plan 25' protiv Jugoslavije. Jugoslavija u svijetlu 'Nürnberških dokumenata', Zagreb 1953, 84-87, 97; N. Milovanović, n. d., I, 284, 304; Коста Николић, Савезници и йокрейи ойӣора у Јуі̄ославији (1941-1945), Београд 2009, 11-12; D. Lukač, Treći Rajh.., II, 508.

${ }^{21}$ Prema izvještaju iz Berlina od istog dana, njemačkim vlastima je uložen protest zbog zadržavanja dva jugoslovenska remorkera i tri šlepa natovarenih koksom i ugljem u Beču, o čemu je Poslanstvo u Berlinu obavijestila Agencija Državne rečne plovidbe u tom gradu (AJ, 334-2-15; AJ, 334-16-41; AJ, 334-17-44; VA, VKJ, k. 11a, f. 2, dok. br. 44 i 55; VA, VKJ, k. 12, f. 5, dok. br. 56). 
no duboko uvređen. Pitanje saobraćaja Dunavom igra veliku, ako ne i presudnu ulogu. Nemačka vlada se boji da ga mi ne onemogućimo, kad to nađemo za shodno, sve da se jugoslovensko-nemački odnosi sad nekako zakrpe. Dodao je, da je ustvari saobraćaj obustavljen kod Bezdana i Prahova (ne zna iz kojih razloga) i da im to nanosi već ogromnu štetu." Velizar Ninčić je tvrdio da "nikakva naša mera ne ometa slobodan saobraćaj nemačkih plovnih objekata Đerdapskim sektorom i našim Dunavom" i da je „preduzeto sve potrebno za obezbeđenje potpuno slobodne plovidbe“. Jugoslovenske oružane snage jesu preduzele određene pripreme za zaprečavanje plovnih rijeka, ali potpuno onemogućavanje plovidbe teško da je postignuto, osim tokom samih ratnih operacija, kada su se na plovnom putu našli ostaci konstrukcija mostova porušenih prilikom povlačenja jugoslovenske vojske i potopljena plovila. ${ }^{22}$

Napad na Jugoslaviju počeo je 5. aprila oko 22 sata, kada je njemačka borbena skupina Đerdap, specijalno formirana odlukom od 1. aprila, koja se nalazila pod komandom 4. udarne grupe 12. njemačke armije i kojoj je dodjeljena četa 800. puka Brandenburg, porinula svoje čamce u Dunav i upala na teritoriju Jugoslavije. Ova skupina, jačine 50-60 ljudi na deset gumenih čamaca, kojoj je naređenje o ovladavanju Sipskim kanalom u noći pred izvršenje Direktive br. 25 izdato 3. aprila, zauzela je saobraćajnicu koja je od Kladova vodila ka Sipu oko 2 sata nakon ponoći, a zatim presjekla telefonske i telegrafske veze na putu Kladovo-Tekija. U isto vrijeme, druga skupina je sa Ade Kale dejstvovala sa ciljem da se onemogući eventualno slanje pojačanja. Prva skupina je ovladala Sipskim kanalom oko 5 sati, zauzela postrojenja lokomotivske vuče i samo naselje Sip, sprečivši jugoslovenske snage da obje lokomotive sa teškim tovarom ubace u kanal. Prvi napad njemačkih kopnenih snaga na jugoslovensku teritoriju upravo je i izveden na Đerdapu sa ciljem da se spreči eventualno teže oštećenje plovnog puta miniranjem ili zaprečavanjem. Radnici lokomotivske vuče i većina vojnika bili su zarobljeni, a rijetki koji su pružili otpor bili su pobijeni. Odbrana Sipskog kanala sastojala se od jedne čete pješadije i jednog voda topova. Komandir voda topova potporučnik Todorović izvršio je samoubistvo vidjevši bezizlaznost situacije $u$ kojoj se našao. U izvještaju Vrhovnoj komandi njemačke kopnene vojske o dejstvima 12. armije slavodobitno je javljeno: „Neprijateljska obala u rejonu 'Gvozdenih vrata', kod Oršave, nakon jednog prepada, nalazi se čvrsto u našim rukama." Otprilike u vrijeme kada je posao na Željeznim vratima završen otpočeo je vazdušni napad na jugoslovensku teritoriju. ${ }^{23}$

${ }^{22}$ AJ, 334-17-44.

${ }^{23}$ Prema jednom dokumentu o radu njemačke obavještajne službe u Đerdapu navodi se da je veče prije njemačkog napada sreski načelnik Leonid Čudnovski, koji je bio 
Jedno od važnijih dejstava jugoslovenske vojske na početku njemačkog napada trebalo je da ima za cilj potpuno onemogućavanje plovidbe kroz Đerdapski sektor. Prema ratnom rasporedu, Komanda Đerdapskog sektora nalazila se u Tekiji, a njen komandant je bio poručnik bojnog broda I klase Josip Grgić. Ona je direktno komandovala grupama za zaprečavanje Sipskog kanala i kanala Juc koje su bile stacionirane u Tekiji i Donjem Milanovcu. Jednu grupu je predvodio sam Josip Grgić, a drugu rezervni poručnik bojnog broda Vinko Petrović. ${ }^{24}$

Remorkeri Vitez i Kumanovo trebalo je da potope po dva šlepa ispunjena cementom i željezom. Brod Vitez, pod snažnom neprijateljskom vatr-

blizak njemačkoj obavještajnoj službi, odvukao znatan dio oficira jugoslovenske vojske iz Sipa. U tom izvještaju stoji: „Čudnovskog su za ovu akciju iskoristili na taj način što je za subotu uveče 5. aprila 1941. godine zakazao banket u Kladovu i sve oficire sa Sipskog kanala pozvao na banket, a vojnicima samog garnizona poslao je veću količinu vina. Dok su se pijani oficiri bivše jugoslovenske vojske vraćali iz Kladova za Sip Nemci su već prešli Dunav preko Ade kod Sipa i u šancu kraj samog puta posmatrali povratak pijanih oficira." (DAMSP, PA, 1947, Đerdapska administracija, f-85, dosije 7, 427335; Aprilski rat, II, dok. br. 157, str. 478; E. Vražalić, n. d., 60; D. Lukač, Treći Rajh..., II, 521-522; V. Terzić, n. d., II, 248, 280, 298, 476; Д. Алексић, н. g., 114, 116-117; Branko Petranović, Srbija u Drugom svetskom ratu 1939-1945, Beograd 1992, 100; N. Milovanović, n. d., II, 7-8; B. Petranović, Istorija Jugoslavije 1918-1978, Beograd 1981, 183; Љубодраг Димић, Истиорија срйске gржавности, III, Србија у Јуїославији, Нови Сад 2001, 214-215; С. Бранковић, н. g., 27-28).

${ }^{24} \mathrm{Na}$ čelu Komande riječne flotile nalazio se, kao komandant, kapetan bojnog broda Edgar Angeli, dok je načelnik Štaba bio kapetan korvete Boris Starov. Prema ratnom planu, snage jugoslovenske riječne flotile bile su raspoređene na Dunavu i Tisi. Na Dunavu su se nalazili: 1. grupa monitora (Sava i Vardar) u Dubovcu (komandant poručnik bojnog broda I klase Milivoj Kockar) i 5. minersko-baražna grupa u Smederevu (komandant kapetan korvete Bogdan Želekovski) za dejstva prema Rumuniji; monitor Drava, 1. minersko-baražna grupa u Bezdanu (komandant poručnik bojnog broda I klase Luka Gomerčić) i 4. minerskobaražna grupa u Erdutu za dejstva prema Mađarskoj. Na Tisi su bili stacionirani monitor Morava u Staroj Kanjiži (komandant poručnik bojnog broda I klase Božidar Aranđelović), 2. minersko-baražna grupa u Senti (komandant rezervni poručnik bojnog broda I klase Stjepan Rumenović) i 3. minersko-baražna grupa u Titelu (komandant poručnik korvete Bogdan Bogdanović) za dejstva prema Mađarskoj. Komandno mjesto riječne flotile nalazilo se na brodu Cer u rejonu Vukovar-Novi Sad. Zadatak riječne flotile bio je višestruk. Riječna flotila je trebalo da bude u sadejstvu sa jedinicama kopnene vojske koje su se oslanjale na tok Dunava i Tise, da zaštiti sopstvena i onemogući saobraćaj plovila neprijateljskih zastava i da pruži podršku u onemogućavanju neprijateljskih snaga u pokušaju prelaska rijeka. Minersko-baražne grupe su imale za cilj zaprečavanje plovnih puteva minama, barikadama i potapanjem plovila, razminiranje plovnih puteva i zaštitu mostova. Takođe, na desnoj obali Dunava, kod Radujevca, Sipa, Smedereva, Grocke, Beograda, Zemuna, Slankamena, Petrovaradina, Iloka, Vukovara i Dalja bila su postavljena po dva topa, kako navodi Velimir Terzić, „sa zadatkom da otvore vatru i potope svako plovno sredstvo sila Osovine i njihovih satelita kada to bude naređeno" (VA, VKJ, k. 3a, f. 1, dok. br. 15; V. Terzić, n. d., II, 172-174, 222, 274, 510, 712-713; B. Antić, Rečna ratna flotila NOVJ, 12-14; Boško Antić, Rat na rekama kroz vekove, Beograd 1986, 179-180; Radiša Savić, Dejstva na plovnim rekama u NOR, Beograd 1977, 5). 
om, oko 3 sata ujutro nije uspio potopiti šlepove na mjestu gdje je to planirano već na nepovoljnom mjestu, izvan Sipskog kanala. Brod je potom doplovio natrag u Tekiju i pokušao uspostaviti vezu sa Komandom. Budući da su veze bile u prekidu i da se iz Sipa javio njemački oficir, posada, sastavljena od dobrovoljaca, odlučuje da ponovo krene ka Sipskom kanalu. Uslijed jake struje i napada njemačkih snaga sam brod je potopljen tek nekoliko kilometara nizvodno, kod Davidovca. Opravdano je postaviti pitanje zašto je brod sa ovakvim zadatkom njemački napad dočekao pozicioniran u Tekiji, desetak kilometara daleko od Sipskog kanala, iako je bilo prijedloga da se premjesti na sam ulaz u kanal. Ni brod Kumanovo nije uspio u naumu da zapreči kanal Juc, pošto je pod vatrom sa rumunske obale i sa jednog rumunskog remorkera, šlepove potopio 1.300 metara uzvodno od ulaza u kanal. Potapanjem šlepova u kanalu Juc i u Sipskom kanalu, kao i ubacivanjem lokomotiva u riječni tok trebalo je da se postigne potpuna obustava plovidbe i da se na taj način nanese nesaglediva šteta njemačkoj ratnoj mašineriji, ali se to nije dogodilo. ${ }^{25}$

Vrlo važna svjedočanstva o jugoslovenskim planovima za zaprečavanje plovidbe kroz Đerdapski sektor ostavio je kapetan bojnog broda Mirko Plajvajs u svojim memoarima Slomljeno sidro. Ovaj školovan i iskusan oficir, najprije austrougarske, a zatim jugoslovenske mornarice, našao se polovinom 1940. na čelu baze ratne flotile u Novom Sadu, a zatim i na mjestu komandanta monitora u Đerdapskom sektoru. Govoreći o planovima Jugoslavije za zaprečavanje Dunava napisao je: „Prema operativnom planu, zadatak monitora bio bi da, surađujući s kopnenom vojskom, spriječi prelazak neprijatelja na našu stranu i da odmah po izbijanju rata onemogući plovidbu Dunavom, pomoću blokade Sipskog kanala. U tu svrhu je bio pripremljen veliki dunavski šlep, natovaren do ruba kamenjem, a koji bi trebao biti potopljen pred ulazom u taj kanal." Još važnije njegovo svjedočanstvo govori o (ne)pripremljenosti Jugoslavije za odbranu Đerdapa: „Ustanovio sam da bi na tom sektoru svaki neprijateljev pokušaj prelaza rijeke na našu stranu mogao biti spriječen i manjim pješadijskim jedinicama, dobrom artiljerijom srednjeg kalibra i protuavionskim baterijama na isturenim točkama. No, od svega toga nisam našao ništa. Najbliže jedinice kopnene vojske su bile 20-30 kilometara od obale, a zbog slabih prometnih veza bilo bi potrebno prilično vremena da dođu do Dunava. Samo na jednom jedinom brežuljku, koji je, istina, dominirao velikim dijelom sektora od V. Gradišta nizvodno, bila su postavljena tri topa najmodernije konstrukcije, tipa 'škoda', ali jedina veza s najbližom kopnenom jedinicom bila je konjska, kojoj je

${ }^{25}$ M. Paunović, n. d., 698-702; C. Бранковић, н. g., 28-29; Д. Лукач, Иниеересовање у нацистииккој Немачкој..., 192; V. Terzić, n. d., II, 279-280; B. Antić, Rečna ratna flotila NOVJ, 15; Isti, Rat na rekama kroz vekove, 180-181. 
trebalo i po više sati do te jedinice i natrag. Inače je čitava granica od V. Gradišta do Prahova bila 'čuvana' - kako sam to mogao približno ocijeniti sa otprilike 80 žandara i carinskih stražara. Katastrofalna i nevjerovatna lakomislenost nadležnih - to je bila moja konačna konstatacija." Bio je oduševljen jedino „izvrsnom idejom“ šefa lokomotivske vuče inž. Petrovića, koji je postavio dodatne kolosjeke, koji su u slučaju rata vodili lokomotive pravo u uzburkane valove Dunava. Na mjestu komandanta monitora na Đerdapu M. Plajvajs nije dočekao početak rata, pošto je u martu 1941. premješten za komandanta odbrane u Selcu. ${ }^{26}$

U Aprilskom ratu jugoslovenska riječna plovila pretrpjela su znatne gubitke. Monitor Drava, pod komandom poručnika bojnog broda Aleksandra Berića, odbio je nalet četiri mađarska monitora u sukobu nedaleko od Batine. Po naređenju komandanta A. Berića, sa monitora je gađan i aerodrom kod Mohača, koji je koristila njemačka avijacija. Uvidjevši cjelokupnu situaciju na bojištima, posada monitora je potopila sva jugoslovenska plovila koja su se nalazila kod Bezdana i uputila se ka Novom Sadu, gdje je trebalo da bude iskrcana, a zatim kopnom, preko Fruške gore, da nastavi put ka unutrašnjosti zemlje. Tokom sedmodnevnog dejstva posada je, poslije proglašenja Nezavisne Države Hrvatske, dobila poziv od komandanta riječne flotile Angelija, koji je sa brodom Cer prešao u Osijek, da se stavi na raspolaganje novoproglašenoj državi. Monitor Drava je potopljen 12. aprila sa oko 60 članova posade, nedaleko od Čiba (današnjeg Čelareva), poslije napada njemačke avijacije. U borbama, neposredno prije potapanja, artiljerijskom paljbom sa broda oborena su tri njemačka aviona. Veliki broj članova posade je poginuo u sukobu sa njemačkom avijacijom, a manji dio je uspio da se domogne obale plivajući. ${ }^{27}$

S obzirom na težinu situacije na frontovima u Jugoslaviji, jugoslovenska plovila su masovno potapana od strane svojih posada kako ne bi pala u ruke okupatora. Na ušću Save u Dunav posade su potopile brodove Vardar, Sava i Morava, a zatim nastavile plovidbu Savom na dva manja remorkera, pošto je, zbog visokog vodostaja Save, prolazak ispod mostova bio onemogućen. U trenutku prolaska remorkera Tanasko Rajić vojska je minirala željeznički most na Savi kod Beograda. Tom prilikom je poginulo 95 oficira i mornara, od 110 ukrcanih ljudi. Ostali, teško ranjeni, nastavili su plovidbu ka Obrenovcu na remorkeru Raška. Svi preostali brodovi su potopljeni kod Obrenovca, a posade su nastavile povlačenje željeznicom.

${ }^{26}$ Mirko Pleiweiss, Slomljeno sidro, Beograd 1978, 159-165.

${ }^{27}$ Vladimir Požeg, Vekovi srpskog pomorstva i rečnog brodarstva, Beograd 2008, 200 202; V. Terzić, n. d., II, 396, 540; Anton Simović, Rečne ratne flotile, Split 1954, 31-32; M. Paunović, n. d., 703-704; B. Antić, Rečna ratna flotila NOVJ, 16-22; Isti, Rat na rekama kroz vekove, 181-182; M. Janković, n. d., 369-378; R. Savić, n. d., 6-15. 
Osim brodova stradalih u bombardovanju, brodari su potopili još 12 brodova dok je brod Drač uspio stići do sovjetskog dijela Dunava, zajedno sa 16 šlepova i 40 članova posade. Brodovi su potapani i kod sela Klenak kod Šapca. ${ }^{28}$

Zbog razvoja situacije na čitavom prostoru Jugoslavije naređeno je da se svi mostovi preko Save i Dunava u okolini Beograda poruše „čim se naše trupe povuku iz Srema i Banata". Vrhovna komanda jugoslovenske vojske naredila je 11. aprila da se izvrše potrebne pripreme za rušenje mostova na Savi „pre prelaza neprijateljskih borbenih kola““ ${ }^{29}$ Jedinice jugoslovenske 6. armije, koje su imale zadatak da brane front prema Rumuniji od sela Brnjice na Dunavu do Begejskog kanala, povlačile su se iz Banata pod naletom njemačkih snaga i u noći 11/12. aprila prešle Dunav, a te noći su i porušeni mostovi. ${ }^{30}$ Porušeni su Most kralja Petra II na Dunavu, željeznički i Most kralja Aleksandra na Savi. Sjećajući se posljednjih dana pred pad Beograda u njemačke ruke major Velimir Piletić naročito je istakao da su Nijemci prilikom bombardovanja ostavili beogradske mostove na Savi i Dunavu potpuno neoštećenima, čime je jasno naglašeno koliko su im oni bili važni. O rušenju mostova V. Piletić je zapisao: „Lepi mostovi, ukras mog rodnog grada, našli su počinak u dnu svojih reka. 'Neprijatelj vas neće koristiti', izgovorih kao utehu i olakšanje." ${ }^{31}$

Porušeni su i drugi dunavski mostovi te noći. U Novom Sadu je, nekoliko minuta prije ponoći, porušen željeznički most koji je nekada nosio ime cara Franca Jozefa, a od 1929. bio Most kraljevića Andreja. Te noći je porušen i Most kraljevića Tomislava, koji je predstavljao jedan od simbola razvoja međuratnog Novog Sada. ${ }^{32}$ Željeznički most je obnovljen tokom

\footnotetext{
${ }^{28}$ Isto.

${ }^{29}$ VA, VKJ, k. 3, f. 4, dok. br. 29.

${ }^{30}$ Aprilski rat, II, pr. br. 1, 845; V. Terzić, n. d., II, 258-259, 388; B. Petranović, Srbija u Drugom svetskom ratu, 105.

${ }^{31}$ Велимир Пилетић, Суgбина срӣскої офиицра, Крагујевац 2002, 45.

${ }^{32}$ Izgradnja Mosta kraljevića Tomislava počela je u drugoj polovini 1921. na mjestu gdje je Dunav izuzetno uzak, a prema austrougarskom projektu inženjera Silarda Zjelinskog iz 1912, čiju realizaciju je omelo izbijanje Prvog svjetskog rata. Koristeći se sredstvima iz njemačkih reparacija Jugoslavija je izgradila i 20. maja 1928. pustila u promet Most kraljevića Tomislava na Dunavu između Novog Sada i Petrovaradina. Svečanom otvaranju mosta, uz gradonačelnika Novog Sada Branislava Borotu i povjerenika Petrovaradina Ivana Jelačića, prisustvovao je i ministar građevina Petar Marković, dok su osvećenje mosta obavili episkop bački Irinej i zamjenik đakovačkog biskupa Andreja Spete. Isporuku i montažu željezne konstrukcije izvršile su dvije njemačke firme. Most je bio dugačak 341 metar, a dobio je ime po drugom sinu jugoslovenskog monarha koji se te godine rodio. Most je imao izuzetan značaj pošto je predstavljao jedinu vezu Srema sa Banatom i Bačkom. Drugi novosadski dunavski most građen je tokom 1882. i 1883. kao Most Franca Jozefa, a od 1929. nosio je ime Most kraljevića Andreja (Мостиови Ново̄̄ Сaga, приредио Велимир Вукмановић, Нови Сад 2005,
} 
okupacije 1942, korišćenjem ostataka konstrukcije razrušenog mosta, kao i mosta demontiranog negdje sa Dona, ali su ga Nijemci porušili prilikom povlačenja 22. oktobra 1944. Taj most je služio samo za njemačke potrebe i bio je pod stalnim nadzorom, kao izuzetno važan vojni objekat. Prilikom bombardovanja saveznici su pokušali da sruše most, ali bezuspješno. ${ }^{33}$

Već 15. aprila, prije zvanične kapitulacije oružanih snaga Kraljevine Jugoslavije, Uprava za vojnu privredu i naoružanje Vermahta donijela je odluku o privremenom konfiskovanju Jugoslovenske rečne plovidbe (JRP) "sa svim njegovim brodskim parkom i postrojenjima na kopnu“. Naređeno je hitno preduzimanje svih mjera "radi brze obnove plovidbe“. Preduzimane su mjere za čišćenje dunavskog plovnog puta dok su ratne operacije širom Jugoslavije još uvijek trajale. Prema izvještajima 2. armije, plovidba Dunavom od Beograda do rumunske granice ponovo je bila uspostavljena 17. aprila, a već u maju mjesecu se mogla odvijati u punom obimu na čitavom toku Dunava kroz Jugoslaviju. ${ }^{34}$ Vrhovna komanda Vermahta, ispostavljajući zahtjeve „državama naslednicama u Jugoslaviji i Grčkoj“, zatražila je decidirano i „pravo plovidbe na Dunavu i njeno obezbeđenje od Beograda do bugarsko-rumunske granice“ ${ }^{35}$ Obezbjeđenje plovidbe na Dunavu figuriralo je kao jedan od najvažnijih zadataka Nijemaca na tlu razorene Jugoslavije od samog početka okupacije. ${ }^{36}$

Nadzor nad riječnim saobraćajem u obavještajnom i kontraobavještajnom smislu bio je u nadležnosti Centra za vezu u Beogradu, preko kapetana korvete Vajsa, dok je za kontrolu koju je vršila brodska i riječna policija bio nadležan viši državni savjetnik Volf. Njemu su bila podređena odjeljenja riječne policije i lučke kapetanije u Zemunu, Beogradu, Pančevu, Smederevu, Velikom Gradištu, Donjem Milanovcu, Kladovu i Prahovu. Za rukovođenje imovinom JRP bio je zadužen viši inspektor za plovidbu kapetan Franc Cenger u svojstvu komesara, čije je sjedište bilo u Beogradu, u Karađorđevoj ulici 43. Njegov zadatak je bio da cjelokupnu flotu koja je pripadala JRP-u, a koja se mogla prikupiti, „najhitnije pusti u tok normalnog saobraćaja". U isto vrijeme, sva brodogradilišna postrojenja koja su radila u okviru Rečne plovidbe KJ morala su biti puštena u rad „radi remonta brodova". Takođe, na brodove kojima je raspolagao kapetan Cegner je postavljao „potrebno i pouzdano osoblje“, a očekivalo se i da se aktiviraju sve

22-27; Велимир Вукмановић, Дунавски мостиови: og извора gо ушћа, Нови Сад 2009, 125$128,134-135)$.

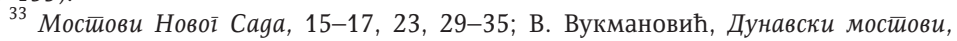
$155-156$.

${ }^{34}$ Aprilski rat, II, dok. br. 271, pr. br. 4, str. 727-728, 963; Д. Алексић, н. g., 206.

${ }^{35}$ Zbornik dokumenata i podataka o Narodnooslobodilačkom ratu naroda Jugoslavije, XII-1, Beograd 1973, dok. br. 1, 9-11.

${ }^{36}$ Isto, dok. br. 222, 256, str. 573-581, 686-688. 
„jugoslovenske postaje ove ustanove“. Samo u prvoj polovini septembra 1941. kroz Beograd je prošlo 129 teretnjaka i tankova nizvodno i 375 uzvodno. Nizvodno su prevoženi ugalj, koks, drva, željezo, cement, crep, šećer, sol, municija, vojni materijal, a uzvodno mineralno ulje, petrolej, ruda hroma, bakar, smola, pirit, šećerna repa, sjemenje suncokreta, uljana repa, soja, žito, proso, mekinje, kukuruz, jaja, grožđe i konoplja. Već na osnovu ovoga možemo vidjeti da se plovidba mnogo više odvijala uzvodno nego nizvodno i da su se uzvodno, ka Njemačkoj, prevozile uglavnom sirovine, a nizvodno vraćali gotovi industrijski proizvodi. ${ }^{37}$ Živost plovidbe kroz Đerdap tokom okupacije ilustruje sljedeća tabela:

Promet kroz Đerdapski sektor 1937-1947 $7^{38}$

\begin{tabular}{|r|r|r|r|}
\hline Godina & $\begin{array}{c}\text { Ukupan broj } \\
\text { objekata }\end{array}$ & Nosivost u tonama & Tovar u tonama \\
\hline 1937 & 9.818 & $4.896 .708,09$ & 2.354 .097 \\
\hline 1938 & 8.220 & $4.002 .137,36$ & 1.851 .823 \\
\hline 1939 & 10.930 & $5.663 .600,74$ & 2.636 .091 \\
\hline 1940 & 10.498 & $6.463 .226,29$ & 2.568 .500 \\
\hline 1941 & 14.325 & $8.170 .491,15$ & 3.952 .187 \\
\hline 1942 & 13.730 & $7.634 .184,13$ & 3.595 .878 \\
\hline 1943 & 16.261 & $9.171 .383,38$ & 3.852 .232 \\
\hline 1944 & 6.289 & $3.632 .332,94$ & 1.661 .352 \\
\hline 1945 & 3.054 & $1.598 .966,88$ & 575.371 \\
\hline 1946 & 3.217 & $1.708 .727,48$ & 816.830 \\
\hline 1947 & 4.334 & $2.315 .624,10$ & 1.090 .866 \\
\hline
\end{tabular}

Plovidba Đerdapom bila je znatno uvećana tokom okupacije, a naročito je bila intenzivna 1943. godine. Tokom njemačke okupacije Jugoslavije, sve poslove na Đerdapu vršila je Uprava Đerdapa i Slapova (Der Sonderausschuß für die Eiserne Tor und Kataraktenstrecke), koju su činili njemački i rumunski predstavnik (G. Marcijus i V. Pela). ${ }^{39}$ Uprava je svoje poslove obavljala preko Specijalnog komiteta u kome je njemački predstavnik bio inž. Hans Volf, dok je Rumuniju predstavljao Konstantin Ene. Dvovalutni sistem za plaćanje đerdapskih taksi postojao je i u tom periodu, s tim što je,

\footnotetext{
${ }^{37}$ Zbornik dokumenata i podataka o NOR-u, XII-1, dok. br. 25, 158, str. 69-71, 419-422.

${ }^{38}$ AJ, Kancelarija maršala Jugoslavije (KMJ), I-4-e/1, Privremeni komitet za upravljanje poslovima Đerdapske administracije.

${ }^{39}$ Počevši od 1942. Bugarska je isticala svoju namjeru da se uključi u upravu Đerdapom, ali bez uspjeha. Iste namjere iskazivale su Mađarska i Nezavisna Država Hrvatska (VA, Nemačka okupatorska vojska (NOV), k. 25b, f. 2, dok. br. 13, 20, 48 i 56; VA, NOV, k. 25b, f. 1, dok. br. 33).
} 
uz rumunski lej, umjesto jugoslovenskog dinara korišćena njemačka marka. Formalni sporazum o njemačko-rumunskoj upravi na Đerdapu potpisan je 28. februara 1942. Najveći dio službenika jugoslovenskog državljanstva predratne Đerdapske administracije bio je otpušten, sjedište Servisa radova je prenijeto iz Tekije u Oršavu, a zbog uvećane plovidbe primljen je znatno veći broj službenika nego što je to bilo predviđeno. Od jugoslovenskih građana zadržano je samo 11 pilota-locova i dvojica radnika u servisima Administracije. ${ }^{40}$

Tokom okupacije, u sklopu diverzantskih akcija i akata sabotaže raznih domaćih naoružanih formacija, na meti su se nalazila industrijska postrojenja od značaja za njemačku privredu, rudnici i saobraćajnice. Upravo iz tog razloga, preduzimane su posebne mjere obezbjeđenja za objekte od „životne važnosti“ za njemačku ratnu privredu, kao što su grad Beograd, zbog svog strateškog položaja, pruga Beograd-Niš-Solun, mostovi preko Dunava i Save, Đerdap i rudnici Bor i Trepča. ${ }^{41}$ Bilo kakav značajniji akt sabotaže na Dunavu mogao je potpuno zaustaviti transport nafte, žita, koksa, bakra i drugih važnih sirovina prema Njemačkoj. Njemačke okupacione snage su oblast Đerdapa držale sigurno u svojim rukama sve do početka septembra 1944. U prvih nekoliko nedjelja obezbjeđenje toka Dunava od Velikog Gradišta do granice sa Bugarskom bilo je povjereno 651. inženjerijskom bataljonu, a počevši od 5. maja 1941. staranje o plovidbi kroz ovaj dio Dunava preuzela je 714. pješadijska divizija. Kako bi se umanjila mogućnost diverzija na Đerdapu, u septembru 1941. evakuisano je stanovništvo iz pojedinih naseljenih mjesta $u$ toj oblasti, a Kazan je bio zaštićen žičanim ogradama. Mjere bezbjednosti su osobito pojačane poslije miniranja trajekta na Dunavu kod Smedereva 20. avgusta. Tokom okupacije i njemačka Dunavska flotila patrolirala je ovom rijekom radi zaštite plovnog puta. ${ }^{42}$ Upravo zbog toga, znatnije sabotaže izvršene su na Savi nego na Dunavu. Samo tokom septembra 1941. dijelovi Posavskog partizanskog odreda potopili su pet plovila (Kraljica Marija, Otadžbina, Žika, Tamiš, Velebit), a Mačvanski odred tri (Slavonija, Boško Jezdić, Vojvoda Brana) i postigli obustavu plovidbe na Savi uzvodno od Zabrežja. Potapanje brodova najčešće je postizano na taj način što je, paljbom sa obale, posada bila natjerana da pristane uz obalu, nakon čega bi putnici i posada bili primorani da napuste

${ }^{40}$ VA, NOV, k. 25a, f. 2, dok. br. 1, 28 i 32; VA, NOV, k. 25b, f. 1, dok. br. 55; DAMSP, PA, 1945, Saobraćaj, f-29, dosije 20, 7736; DAMSP, PA, 1945, Saobraćaj, f-29, dosije 17, 7674; DAMSP, PA, 1946, Dunav, f-20, dosije 23, 15519; AJ, 331-81, br. 330.

${ }^{41}$ Zbornik dokumenata i podataka o NOR-u, XII-1, dok. br. 154, str. 404-407; Zbornik dokumenata i podataka o Narodnooslobodilačkom ratu naroda Jugoslavije, XII-2, Beograd 1976, pril. I, str. 1004, 1125.

${ }^{42}$ Zbornik dokumenata i podataka o NOR-u, XII-1, dok. br. 45, str. 105-110; Zbornik dokumenata i podataka o NOR-u, XII-2, dok. br. 57, str. 306-311. 
brod, a zatim je prazan brod potapan. Krajem septembra iste godine nekoliko plovila moćne mađarske riječne ratne flotile uplovilo je u Beograd sa namjerom da štiti saobraćaj na Savi. ${ }^{43}$

Pokušaji ometanja njemačke plovidbe nastavljani su uprkos svim mjerama bezbjednosti, pa je u oktobru „brodski saobraćaj na Dunavu bio ometan od ustanika, naročito kod Velikog Gradišta. Brodovi su ponovo bili obasipani vatrom, a više malih čamaca i dereglija je zaplenjeno ili potopljeno." Bilo je primjera i potpune obustave civilnog putničkog saobraćaja nizvodno od Smedereva, kao i nemogućnosti pristajanja šlepova nizvodno od Smedereva „zbog noćnih prepada na srpskoj strani Dunava“. Nijemci su, upravo zbog toga, brižljivo čuvali dunavski plovni put kroz Đerdap. Njemačkoj dunavskoj flotili je od sredine 1942. u čuvanju dunavskog plovnog puta pomagala i mađarska riječna flotila, čija su plovila patrolirala od Novog Sada do Vukovara, naročito se starajući o Beočinu, koji je imao izuzetnu važnost zbog fabrike cementa. ${ }^{44}$ Stražarski garnizoni, kako navodi Milan Terzić, bili su smješteni u Velikom Gradištu, Golupcu, Dobri i Donjem Milanovcu, a patrolni čamci su se često kretali kroz Sektor. Govoreći o stanju u okupiranoj Srbiji 1943. godine, Stevan K. Pavlović piše da su, u tom trenutku, pod neposrednom njemačkom okupacijom bili još samo okolina Beograda, Borski rudnici i priobalni pojas od $150 \mathrm{~km}$ duž Dunava. ${ }^{45}$ U njemačkim izvještajima o situaciji na okupiranom području najčešće je pisalo da se saobraćaj Dunavom odvija neometano, a samo je sporadično u izvještajima stajalo da „pojedinačne grupe nastoje da ometaju saobraćaj Dunavom". ${ }^{46}$

Prostor istočne Srbije - od obala Dunava pa do Morave - imao je naročit strateški značaj za pokrete otpora u Jugoslaviji, pa se u početnoj fazi borbi protiv okupatora Komunistička partija Jugoslavije (KPJ) u znatnoj mjeri oslanjala na ovo područje. Procjena je bila da će se, kao što je tok operacija kasnije i pokazao, ovdje najprije moći susresti sa Crvenom armijom „kada ona provali iz Moldavije preko Vlaške, stigne na Karpate i

${ }^{43}$ Zbornik dokumenata i podataka o NOR-u, XII-1, dok. br. 158, 170, str. 419-422, 448-450; Д. Алексић, н. g., 220, 228; В. Petranović, Srbija u Drugom svetskom ratu, 229; Jovan Marjanović, Ustanak i Narodno-oslobodilački pokret u Srbiji 1941, Beograd 1963, 2627, 212, 478; B. Petranović, Istorija Jugoslavije 1918-1978, 224-225, 314; B. Antić, Rečna ratna flotila NOVJ, 27-28; R. Savić, n. d., 22-26.

${ }^{44}$ Zbornik dokumenata i podataka o NOR-u, XII-2, dok. br. 121, str. 600-605.

${ }^{45}$ Zbornik dokumenata i podataka o NOR-u, XII-1, dok. br. 196, str. 508-510;

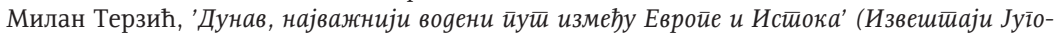
словенској краљевској влаgи у Друіом свешском райу), Војноисторијски гласник, бр.

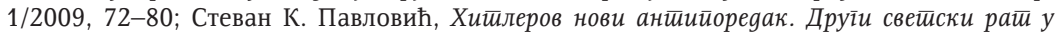
Јуі̄ославији, Београд 2009, 108; В. Antić, Rečna ratna flotila NOVJ, 29.

${ }^{46}$ Zbornik dokumenata i podataka o NOR-u, XII-2, dok. br. 117, str. 583-590. 
Dunav“. Istočna Srbija je bila poprište djelovanja niza partizanskih i četničkih odreda, koji su u zajedničkoj akciji uspjeli zauzeti Veliko Gradište na Dunavu 20. septembra 1941. Tom prilikom nije nanijeta znatnija šteta njemačkim plovilima. Upravo zbog važnosti ovog dijela Srbije i njemačke snage su preduzimale snažne operacije sa ciljem obezbjeđenja dunavskog plovnog puta i eksploatacije Borskog rudnika. Do kraja 1941. partizanske snage su na tom području bile znatno umanjene, dok se četnička organizacija uspjevala održati. ${ }^{47}$

Važno polje djelovanja za odrede Jugoslovenske vojske u otadžbini (JVuO) bio je dunavski plovni put, odnosno Đerdapski sektor, koji se nalazio u dometu dejstvovanja Komande istočne Srbije. Na mjestu komandanta istočne Srbije nalazio se major Velimir Piletić, dok je načelnik Štaba bio kapetan I klase Siniša Ocokoljić. Da je važnost Dunava i Đerdapa za Njemačku uviđana svjedoči i jedna depeša Dragoljuba Mihailovića u kojoj piše: „Nemci mnogo strahuju za Đerdap jer nemaju dovoljno vagon-cisterni za prevoz nafte železnicom. ${ }^{\text {" }}{ }^{8}$ Vrhovna komanda JVuO raspitivala se $u$ februaru 1943. o tome da li su Nijemci podigli neki most na Dunavu „od ušća Morave pa nizvodno“, a "naročito da li ima mostova kod V. Gradišta, Kostolca i D. Milanovca“. Vrhovnu komandu je zanimalo od kog su materijala izrađeni ti mostovi, u koju svrhu su se koristili i koje saobraćajnice su vezivali. Britanci su uporno insistirali na izvođenju što efikasnijih akata sabotaže na važnim saobraćajnicama i objektima, poput rudnika Trepča i Bor, fabrike Sartid u Smederevu, saobraćajnica u dolinama Morave i Ibra. Strateška važnost ovog dijela Srbije ogledala se i u prisustvu nekolicine britanskih oficira, koji su se na taj prostor spuštali padobranima. Blizina rudnika, dunavskog plovnog puta, mogućnost prelaska na teritoriju Rumunije, ali i mogućnost uspostavljanja veze sa političkim organizacijama u Bugarskoj bili su razlog njihovog dolaska. ${ }^{49}$

Velimir Piletić je potvrdio u svojim memoarima da su se Britanci interesovali za mogućnosti sprečavanja saobraćaja na Dunavu, „važnoj komunikaciji koja vodi na Istočni front, prema SSSR-u“. On navodi da su pripadnici njegovih jedinica još 1941. pucali na njemačke brodove, ali „bez rezultata". Postignuto je jedino da Nijemci postanu još oprezniji i da brodove

${ }^{47}$ Velimir Piletić o tome piše: „Poslednji ostaci, oko desetak partizana, nestali su polovinom 1943. godine. Tako je Istočna Srbija za sve vreme okupacije bila u našim rukama, do pojave sovjetske armije na našoj granici na Dunavu." (В. Пилетић, н. g., 76; B. Petranović, Srbija u Drugom svetskom ratu, 158, 160-161, 187, 210-211, 244; J. Marjanović, n. d., 112; B. Petranović, Istorija Jugoslavije 1918-1988, II, Beograd 1988, 82-83, 113-114).

${ }^{48}$ Zbornik dokumenata i podataka o Narodnooslobodilačkom ratu naroda Jugoslavije, XIV-1, Beograd 1981, dok. br. 105, str. 342-360.

${ }^{49}$ VA, Četnička arhiva (ČA), k. 96, f. 19, dok. br. 2; B. Petranović, Srbija u Drugom svetskom ratu, 244; N. Milovanović, n. d., II, 203; В. Пилетић, н. g., 83, 86-90. 
naoružavaju „automatskim oružjem i topovima manjeg kalibra“. Od jedinica pod komandom V. Piletića traženo je da se prebace preko Dunava na rumunsku teritoriju i da vrše sabotaže na pruzi koja, poslije Oršave, prati dunavsku obalu. Britanci su, kao ispomoć, nudili i gumene čamce kojima su se diverzantski odredi mogli prebaciti na drugu obalu. Aprila 1943. u Homolje je stigla britanska misija pod vođstvom majora Erika Grinvuda, čiji je zadatak bio organizacija napada na njemačke plovne objekte na Dunavu i izvođenje diverzantskih akcija u rudniku bakra u Boru.$^{50}$ Iz istih razloga je i iskusni đerdapski pilot Tadija Udovičić, rodom iz okoline Užica, poslat u štab Velimira Piletića 18. septembra 1943. „kao stručnjak na Dunavu“. Osim T. Udovičića, i piloti Đorđe Trandafilović i Jerolim Vukić bili su bliski pokretu Dragoljuba Mihailovića, a postoje određeni podaci da su u 1943. i 1944. pokušavali izvesti niz sabotaža na Dunavu, potpomognuti od britanskih tajnih službi. Već prilikom prvog dolaska T. Udovičića u štab V. Piletića sačekala su ga dva britanska oficira i raspitivali se o najpogodnijem dijelu Đerdapa za sabotaže. Prema savjetu T. Udovičića izvršen je napad na jedan njemački brod kod mjesta Lepena, sa ciljem da se pobije posada i da brod bez ikakve kontrole sam potone. Napad je izvršen noću 25. septembra 1943. Kapetan broda je ubijen, ali je ostatak posade uspio da brod skrene ka rumunskoj obali i izbjegne potapanje. Krajem oktobra 1943. izvršena je akcija nedaleko od mjesta Boljetin, u klisuri Gospođin vir, kada su napadnuta dva remorkera sa po dva šlepa. Tom prilikom su potopljena dva plovila, ali plovidba nije znatnije onemogućena. ${ }^{51}$

Procjenjeno je da se najveća šteta njemačkoj plovidbi može nanijeti ukoliko se izvrši diverzija na Sipskom kanalu. Konsultacije sa đerdapskim pilotima-locovima, koji su pripadali jedinicama pod komandom V. Piletića, dovele su do najizvodljivije mogućnosti za zaprečavanje Sipskog kanala. Odlučeno je da se iz „lakog ručnog oružja“ ubiju pilot-loc i kapetan broda, ali da se to uradi na tačno određenom mjestu, kako bi brod udario o stjenu prije nego što bi rezervni oficiri mogli preuzeti upravljanje. Pucanje na brod nije dalo rezultata, ubijen je jedan mornar, sa broda je odgovoreno vatrom, a Nijemci su upozoreni „da ubuduće obrate pažnju na kanal“. Velimir Piletić navodi da su narednih dana mediji okupirane Srbije javili da je „zbog napada na brod kod Sipskog kanala streljano 160 Srba iz Banjičkog logora“. ${ }^{5}$

${ }^{50}$ N. Milovanović, n. d., II, 204; В. Пилетић, н. g., 88; Коста Николић, Генерал Драі̄ољуб Михаиловић (1893-1946), Београд 2005, 196; К. Николић, Савезниии и йокретии ойūopa.., 200-201.

${ }^{51}$ DAMSP, PA, 1946, Dunav, f-20, dosije 24, 15560; DAMSP, PA, 1947, Đerdapska administracija, f-85, dosije 7, 427331; DAMSP, PA, 1947, Đerdapska administracija, f-85, dosije 7, 427358; DAMSP, PA, 1947, Đerdapska administracija, f-85, dosije 7, 427334.

${ }^{52}$ В. Пилетић, н. g., 88-89. 
Velika Britanija, ali i Jugoslovenska kraljevska vlada u Londonu imali su podatke o „živom saobraćaju na Dunavu“, kao i o tome da smederevski Sartid punim kapacitetom izrađuje dijelove za šlepove neophodne za dunavsku plovidbu. Dunav je dodatno dobijao na značaju s obzirom na mogućnost proširenja ratnih operacija prema Turskoj. Prema izvještaju majora Perića, jugoslovenskog obavještajca u Carigradu, čak $80 \%$ njemačkog snabdijevanja tečnim gorivom dolazilo je Dunavom, a pokraj Beograda je svakodnevno prolazilo 100-200 plovila. Zbog toga je presjecanje dunavskog plovnog puta, sa stanovišta saveznika, moglo nanijeti znatne poteškoće njemačkoj ratnoj mašineriji. O značaju Dunava razgovaralo se i na sjednicama jugoslovenske emigrantske vlade. Govoreći o jugoslovenskoj spoljnoj politici u uslovima rata i perspektivama u posljeratnom periodu, ministar šuma i ruda Jovan Banjanin je, između ostalog, naglasio: „Napominjem još i pitanje Dunava kao velike evropske saobraćajne linije. Upozoravam da se već u engleskoj javnosti nagoveštava radikalnija internacionalizacija Dunava nego što je dosad bila. To može dovesti dotle da izgubimo gotovo svaki slobodan uticaj na Dunavu, što bi znatno oslabilo naš politički i ekonomski položaj u Srednjoj Evropi." ${ }^{33}$

S obzirom na razvoj situacije na frontovima u Evropi, saveznici su dobili mogućnost da dejstvima iz vazduha direktno naštete plovidbi na Dunavu. U proljeće 1944. saveznička avijacija je, u sklopu taktičkog bombardovanja važnih ciljeva na tlu Jugoslavije, pokušala nanijeti štetu njemačkoj plovidbi i komunikacijama na Dunavu. ${ }^{54}$ Prilikom akcija na jugoslovenskoj teritoriji bačen je veliki broj mina u Dunav. Potapanjem nekoliko plovila i ubacivanjem mina saveznička avijacija je uspjela da makar na određeno vrijeme prekine normalno odvijanje njemačke plovidbe. Prve savezničke akcije postavljanja mina u Dunav izvedene su u noći 8/9. aprila 1944, kada je položeno oko 40 akustičnih mina u korito Dunava kod Bazijaša, Smedereva i Beograda. Avioni koji su imali zadatak polaganja mina u Dunav poletali su sa pista u Italiji. Do 15. aprila oni su položili još 137 mina (uglavnom akustičnih, težine $500 \mathrm{~kg}$ ). Prema izvještaju od 23. aprila postojali su sigurni podaci o potapanju tri plovila. Brod Tuln je potopljen nizvodno od Pančeva, jedan šlep kod Belegiša, a potopljen je i jedan šlep iz povorke broda Senjanin Ivo. U tom trenutku nije bilo pouzdanih podataka o tome

${ }^{53}$ Jugoslavenske vlade u izbjeglištvu 1941-1943. Dokumenti, priredio Bogdan Krizman, Beograd 1981, 413; М. Терзић, Дунав, најважнији воgени йуй..., 76.

${ }^{54}$ Kako u svom istraživanju navodi Milan Terzić bombardovanje mnogih ciljeva u Jugoslaviji, između ostalog i mosta između Beograda i Pančeva na Dunavu i mosta na Savi u Beogradu, tražio je i ministar vojni Dragoljub Mihailović u depešama slatim između marta 1942. i novembra 1943 (Milan Terzić, Jugoslovenska kraljevska vlada, general Dragoljub Mihailović i savezničko bombardovanje ciljeva u Jugoslaviji 1942-1944. godine, Tokovi istorije, br. 1-2/2005, 81-111). 
koliko je plovila oštećeno u bežanijskom zimovniku, koji se takođe našao na udaru savezničke avijacije. Sva signalizacija na jugoslovenskom dijelu Dunava, prema instrukcijama njemačkih okupacionih vlasti, bila je ugašena kako bi štete na plovnom putu bile što manje. ${ }^{55}$ Žestoko bombardovanje Beograda oštetilo je oba beogradska mosta i izazvalo prekid u saobraćaju Dunavom. Tokom nekoliko dana maja položene su još 364 mine, uglavnom oko Željeznih vrata. Mine su potom polagane u dva navrata, tokom juna i jula mjeseca. Tom prilikom je i njemačka protivavionska odbrana oborila nekoliko savezničkih aviona. Za čišćenje toka Dunava od savezničkih mina korišćena su i dva specijalno uređena hrvatska broda Zagreb i Petar Zrinjski, na kojima je bilo 104 podoficira i vojnika. ${ }^{56}$

Oštećenje mostova, potapanje plovila i polaganje mina u Dunav bili su ciljevi i savezničkog bombardovanja početkom septembra 1944. U pogledu štete nanijete dunavskoj plovidbi bombardovanje u septembru je bilo daleko djelotvornije. U bombardovanju od 3. septembra most na Dunavu kod Beograda, kako je zapisano u dnevniku Komande Grupe armija „F“, „srušen je na dužini 180 metara“, čime je prelaz preko mosta bio onemogućen, a plovidba izuzetno otežana. ${ }^{57}$ Osim znatnijeg oštećenja mostova, položen je i veći broj mina koje su u narednom periodu pričinjavale značajne poteškoće plovidbi, kako u završnoj fazi rata, tako i u poratnim godinama. Prema nekim procjenama, saveznički avioni su položili oko 1.200 mina u Dunav (od čega gotovo $1.000 \mathrm{u}$ jugoslovenski dio), od kojih je potopljeno ili oštećeno oko 200 plovila. Kasnije su veliku količinu mina u Dunav ubacili i Nijemci, prilikom povlačenja. Pojedini autori su ovu savezničku akciju nazivali „minskim ratom“. Procjenjuje se da je u periodu od 1. aprila do 30. juna od mina ili napada iz vazduha potopljeno 99 plovila, od čega 5 putničkih brodova, 23 remorkera, 4 motorna teretna broda, 1 motorni tanker, 55 šlepova i 11 šlepova-tankera. Tom prilikom je stradalo 140 ljudi. $^{58}$

${ }^{55}$ Arhiv Srbije (AS), Ministarstvo saobraćaja, f. 2, Izveštaj gospodinu ministru saobraćaja od 23. aprila 1944.

${ }^{56}$ Zbornik dokumenata i podataka o Narodnooslobodilačkom ratu naroda Jugoslavije, XII-4, Beograd 1979, dok. br. 102, str. 458-469.

${ }^{57}$ Isto, pril. I, str. 951.

${ }^{58}$ Procjenjuje se da je u toku Drugog svjetskog rata u Dunav bilo položeno 3.168 nekontaktnih, 190 sidrenih i oko 200 plutajućih mina. Prema jugoslovenskim i sovjetskim podacima u jugoslovenski dio Dunava, Save i Drave bilo je položeno 1.340 mina tokom rata, od čega su saveznici položili 983, jugoslovenska kraljevska vojska 200, njemačke snage $110 \mathrm{i}$ rumunska vojska 47 (B. Antić, Rat na rekama kroz vekove, 204-205; B. Antić, Rečna ratna flotila NOVJ, 131-133, 197-198; Nikola Safonov, Upotreba mina na Dunavu u Drugom svetskom ratu, Mornarički glasnik, br. 3/1980, 511-519; Milovan Dželebdžić, Dejstva na komunikacije u Jugoslaviji od 1. do 7. septembra 1944. godine - operacija Ratweek, Vojnoistorijski glasnik, br. 3/1970, 7-61; Ђоко Трипковић, Беоі̄pag ӣog бомбама, Београд 1999, 63). 
Nezadrživo napredovanje Crvene armije duž Dunava krajem avgusta i početkom septembra 1944. i prelazak Rumunije i Bugarske na stranu antifašističke koalicije potisnuli su njemačku silu sa donjeg Dunava. Kada je Crvena armija izbila i na obalu Đerdapa sa rumunske strane, početkom septembra, Dunav je za Njemačku postao samo saobraćajnica kojom je trebalo evakuisati dio ljudstva i opreme sa Jugoistoka. Dunav je prestao da bude saobraćajna arterija Rajha i postao je snažan odbrambeni bedem prostora na kome se njegova vlast pokušala održati. Dotadašnja „kičma Rajha“ postala je posljednja nada da se prodor sa Istoka ipak može zaustaviti. 
Milan Gulić

\section{THE IMPORTANCE OF THE DANUBE AND THE IRON GATES DURING THE MILITARY OPERATIONS IN YUGOSLAVIA 1941-1944}

\section{Summary}

The strategic, traffic and economical importance of the Danube waterway was particularly pronounced during the German expansion towards the Southeastern Europe. As this river became "the backbone of the Reich", a complex diplomatic game, in which the intelligence services of several countries took part, was played for it. The increase in the importance of the Danube waterway influenced the substantial increase in the importance of Iron Gates, as this was, in terms of navigation, the most complicated part of the course of this great European river. The British attempts to sabotage German navigation on the Danube were especially intensive during the first two war years in Europe (1939-1941). The purchase of vessels, bribery of the Iron Gates pilots and attacks with explosives on the steep coasts of the Iron Gates, were some of the ways of fight against the intensive German river traffic. The sector of Iron Gates was the first part of the Yugoslav territory that suffered the German attack, during the last hours of April $5^{\text {th }}$. In the moment when the bombing of Belgrade and other Yugoslav cities started, Sip, the Sip Channel and the locomotive traction were already firmly in the German hands. Despite the attempts to hinder the German navigation made by the Yugoslav Army in the Homeland, supported by the British secret service, Iron Gates and the Danube waterway through Yugoslavia remained firmly in the German hands until September of 1944. Thereafter the Danube was one of the routs by which the Red Army progressed and the German forces retreated. 